\title{
On the Reproduction and Development of the Conger.
}

\author{
By
}

\section{J. T. Cunningham, M.A.,}

Naturalist to the Association.

\section{Review of previous Observations on Sexually Mature Conger.}

BeFore the Laboratory of the Association was built, it had often been observed in other aquaria that female conger after living for some time in captivity, feeding regularly and voraciously, and growing with considerable rapidity, passed into a swollen and apparently gravid condition and then died. Such conger when dissected after death were invariably found to contain enormously developed ovaries or roes, which entirely filled up and distended the abdominal cavity, and pressed the intestine and other abdominal organs into as small a space as possible. The following are the principal records of cases in which this has been observed.

R. Schmidtlein* gives an account of the occurrence in the aquarium of the Zoological Station of Naples in a paper published in 1879. He writes, "All that we can say concerning the reproduction of the conger, is that sometimes the body of large specimens became considerably swollen as though distended with gas, and these specimens hung for some days at the surface of the water on their sides, without eating and without the power of swimming, and then died. When opened, the abdominal cavity was found filled, almost to bursting, with colossal masses of eggs, and all the organs were compressed and reduced to a minimum. In some of these specimens some small masses of eggs were extruded even during life, but the deposition of large numbers of eggs never occurred. All died from the presence of the excessive numbers of eggs which from causes difficult to understand could not be expelled from the body." In a tablet published the same year, the same author states that

* Beobachtungen über die Lebensweise einiger Seethiere innerhalb der Aquarien der Zoologischen Station, Mittheil. aus der Zoolog. Station zu Neapel., Band i, 1879, p. 492.

† Beobachtungen über Trächtigkeits- und Eiablage-perioden verschiedener Seethiere, Mitt. Zoolog. Stat. Neapel., Band i, 1879, p. 135. 
two specimens in this condition died in the middle of August, and he adds that large numbers of young conger scarcely $3 \mathrm{~cm}$. ( $1 \frac{1}{4}$ inches) long are captured in the middle of April. Schmidtlein does not give the measurements of the gravid conger which he mentions, but he calls them large, and in another place says that the fish grows to a length of over 2 metres ( 6 feet), so that it is probable the gravid conger were 5 or 6 feet in length.

Similar observations upon female conger are recorded by Dr. Otto Hermes, the Director of the Berlin Aquarium, in the Zoologischer Anzeiger, vol. iv, 1881. Dr. Hermes states that he is convinced that the development of the ovaries of the conger in captivity is often a cause of death. When some females which had died in the Berlin Aquarium were opened, the ovaries were found to be much enlarged, and one which died in the Frankfort Aquarium was actually burst by the extraordinary development of the ovaries. This specimen weighed $22 \frac{1}{2} \mathrm{lbs}$., the ovaries weighed $8 \mathrm{lbs}$, and the number of eggs in them was calculated to be 3,300,000.

According to Francis Day (Fishes of Great Britain and Ireland) a female conger which died in the Southport Aquarium in June, 1876, weighed $15 \frac{1}{4} \mathrm{lbs}$, and the ovaries $7 \mathrm{lbs}$, the number of eggs in which was calculated at $6,336,512$. It is evident that these calculations are probably not very accurate, for according to the latter there would be nearly a million of egg's to $1 \mathrm{lb}$. of ovary, while according to that of Hermes, there would be only about one million to $6 \mathrm{lbs}$. of ovary.

These are the only published observations concerning the ripe ovary of the conger that I have been able to find. With regard to the structure of the ovaries the most complete account is that given by Brock* in 1881, and founded on observations made at Naples. I have in a previous number of this Journal briefly described the external structure and relations of the ovaries. There is one ovary on each side of the mesentery suspending the intestine. Each consists of a long ribbon-like membrane, attached dorsally, with a free edge ventrally. The median side of the ribbon is smooth and flat, the lateral side bears a series of very numerous thin plates or lamellæ, attached to the ribbon-like membrane edgewise and transversely, and in contact with one another by their faces like the leaves of a book. These lamellæ contain the numerous small ova. Thus the ovary is not a closed tube as in most fishes, and consequently the eggs when they leave the ovary lie free in the bodycavity, whence they escape by an aperture behind the anus.

We have next to ascertain what was known up to the commence-

* Untersuchungen über die Geschlechtsorgane einiger Muraenoiden, Mitt. Zool. Stat. Neapel., Band ii, p. 415.

NEW SERIES.-VOL. II, NO. I. 
ment of my own observations concerning the male conger. The most convenient publication to start from in this inquiry is Hermes' paper already mentioned. The principal subject of this paper was the discovery of ripe testes full of ripe actively motile spermatozoa in a specimen of the conger. The specimen was one of a number caught near Havre, and sent to the Berlin Aquarium in the autumn of 1879. These specimens when they arrived were 60 to $70 \mathrm{~cm}$. long (2 feet to 2 feet 4 inches). They all throve in the aquarium and grew rapidly with the exception of one, which increased very little in size, and which died on June 20th, 1880 . It was then $74 \mathrm{~cm}$. (29 $\frac{1}{10}$ inches) in length. When this specimen was opened organs were seen in it which looked like ripe testes, and when a cut was made in one of these milt flowed from the incision ; this milt was found on examination under the microscope to be swarming with actively moving spermatozoa.

The form and size of the ripe testes are carefully described by Hermes. Each was an elongated laterally compressed mass fastened at the side of the air-bladder by a suspending membrane. The greatest breadth of the organ was $18 \mathrm{~mm}$. ( $\frac{7}{10}$ ths inch), its greatest thickness from side to side $9 \mathrm{~mm}$. ( $36 \mathrm{inch})$. Each organ extended through nearly the whole length of the body-cavity, commencing near its anterior end and continuing some distance behind the anus. A number of transverse fissures divided each organ into several lobes, namely five in the right organ, and about the same number in the left. At the base of each organ was a closed duct or vas deferens through which the milt was conveyed to the exterior. Opposite the rectum a downward branch passed from each vas deferens, and these two branches united to open by a single aperture behind the anus to the exterior. Hermes points out that the testes of the conger discovered by him, correspond, when allowance is made for the fact that they were ripe and fully developed, very perfectly with the lobed organs of the common eel described by Syrski in 1874 . He concludes, therefore, that Syrski's organ is, as that author believed, the testis of the male eel. The conger further agrees with the common eel in the relation of the size of the male to that of the female, Syrski having found that the male eel was considerably smaller than the female.

Dr. Syrski,* while holding the post of Director of the Museum of Natural Sciences of Triest, was commissioned by the authorities of that town to ascertain the spawning season of the fishes of the neighbourhood. He included the eel in his researches, and con-

* My knowledge of the investigations of Syrski and Jacoby is derived from a translation of Jacoby's work on The Eel Question, in the Report of the I.S. Commissioner of Fisheries for 1879 . Washington, 1882 
sidering that in many animals the male is smaller than the female, he began to look for male eels among the smaller specimens. In the second specimen he examined, which was $40 \mathrm{~cm}$. (16 inches) in length, he discovered the organs which he identified as testes. His conclusion as to their nature has been confirmed by all subsequent inquirers, although no one has yet found these organs in the ripe condition, and thus brought the final evidence of demonstrating the ripe spermatozoa of the eel.

The largest male eel observed by Syrski was $43 \mathrm{~cm}$. (17 inches) in length. But Dr. L. Jacoby, who investigated the eel both at Trieste and Comacchio after Syrski, in 1877, found males as long

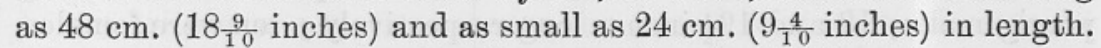
The female eels reach a length, according to Jacoby, of one metre (39 inches) and the thickness of a man's arm, but the majority of adult females which migrate in autumn to the sea are not longer

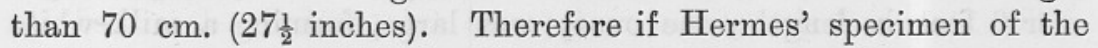
male conger is of the average size of the male in that species, then there is a much greater difference in size between the sexes in the conger than in the eel. The male conger discovered by Hermes was 2 feet $5 \frac{3}{5}$ inches long, while adult females are 5 to 7 or even 8 feet in length. The largest male eel recorded by Jacoby was 1 foot $7 \frac{1}{5}$ inches long, while adult females are only 2 feet 4 inches to 3 feet 3 inches long.

Brock, in his account of the researches he made at Naples, does not include any discussion of the relative sizes of the two sexes. Of the conger he merely says that he examined forty-five specimens, of which the males and females were about equal in number. $\mathrm{He}$ states that he obtained only one male which was perfectly ripe, and that he got this in the middle of November. The size of this specimen he neglects to mention. Of the female sex Brock describes no ovaries far advanced in development, and here also he neglects to mention the size of the specimens which he examined. Of the common eel Brock only states that out of ninety specimens of 35 $\mathrm{cm}$. (14 inches) in length and under which he examined, seventy-nine or 88 per cent., were males, and among those of 35 to $40 \mathrm{~cm}$. (14 to 16 inches) in length six were males.

\section{History of my own Observations.}

I have now to record the observations and experiments on the conger which I have made at the Plymouth Laboratory from November 7th, 1887, up to the end of the year 1890. I find that my notes on the conger in No. 2 old series of this Journal, although 
dated February 29th, 1888, only comprise my observations up to November 7th, 1887, at which time I had not met with a male specimen.

On November 17th I bought eighteen small specimens on the fishquay. The smallest of these was 1 foot 4 inches, the largest 2 feet 8 inches long. One of them, 1 foot 8 inches in length, was a male with well-developed but not ripe testes. The testis was $7 \mathrm{~mm}$. broad and $2 \mathrm{~mm}$. thick (about $\frac{1}{4}$ inch broad, $\frac{1}{12}$ inch thick). In form and relations this testis agreed with the description given by Hermes, except that there was no division into lobes; the organ was continuous from end to end. Two other specimens were very young males, 18 and $19 \frac{1}{2}$ inches long respectively ; ten were females, and in five of the smallest the reproductive organ was so undeveloped that the sex could not be determined.

On December 4th I examined the ovary of a very large conger over 6 feet in length; the ovary was large, forming a milk-white opaque elongated mass on each side of the body-cavity. The organ was $8 \mathrm{~cm}$. wide, the ova or eggs visible as separate grains to the unaided eye. Measured under the microscope the eggs were found to be $.5 \mathrm{~mm}$. in diameter; they were perfectly opaque and granular, and spherical in shape. The ovary contained, besides very numerous ova, a good deal of fat-tissue.

On March 2nd, 1888, I got the roe of a large conger, 5 or 6 feet long, from the fish-quay. The ova in the roe were visible to the unaided eye, and when measured were found to have a diameter of $\cdot 5$ to $\cdot 7 \mathrm{~mm}$.

In ovaries less developed than these the ova are not separately visible to the unaided eye, and can only be seen when a piece of a lamella is examined with the microscope. The appearance then

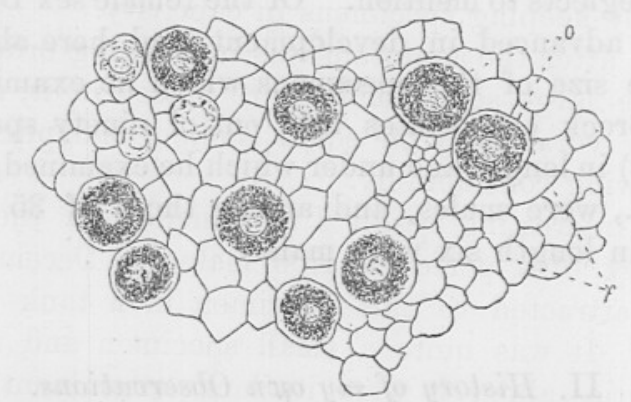

FIG. 1.-Portion of lamella from immature ovary of conger under low power of the microscope. o. Ova. $f$. Fat-cells.

presented by the fresh tissue is that shown in the woodcut, fig. 1 ; the small ova are still transparent enough to show the germinal 
vesicle in the centre, and they are irregularly distributed throughout the fat-tissue which makes up the greater part of the bulk of the ovary. The conger from which the figure was taken was 5 feet 3 inches long, 241 $\frac{1}{2} \mathrm{lbs}$. in weight, and captured and killed on October 6th. Fig. 2 shows a portion of a lamella of the ovary of an eel 22 inches long killed December 10th; the ova here were $\cdot 14 \mathrm{~mm}$. in diameter. Fig. 2 is from a more highly magnified image than fig. 1, and the ova are also somewhat more developed.

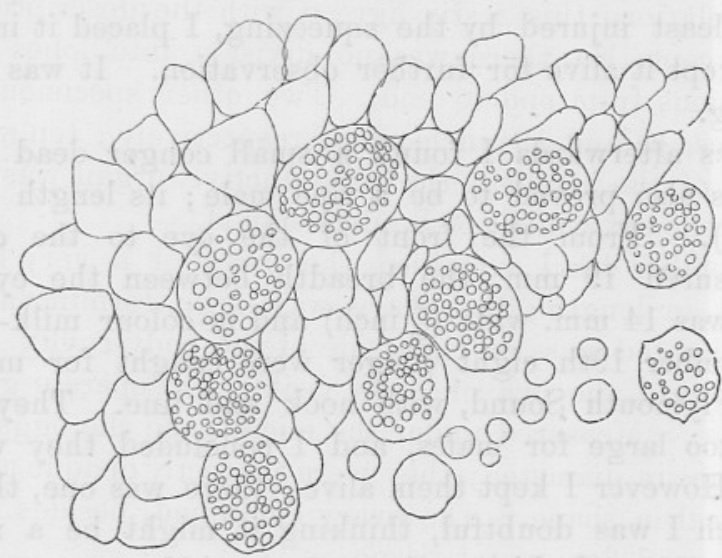

FiG. 2.-Portion of lamella from immature ovary of common eel.

The aquarium of the Plymouth Laboratory was filled with seawater and ready for use by June 30th, 1888. Before this time, as appears from the above observations, I had not succeeded in procuring ripe conger, either males or females, from the fishermen; and I hoped to obtain more light on the subject of the reproduction of the species by keeping specimens in captivity.

Very soon after the aquarium was in working order several living conger, some large some small, were placed in it, and they throve well, feeding voraciously on squid (Loligo) and pilchard, and some of them growing considerably.

The first interesting result I obtained from the aquarium was the discovery of a perfectly ripe male on December 13th. My notice was attracted to this specimen in a tank by its peculiar appearance. It was quite a small specimen and somewhat thin; the peculiarities about it were its large prominent eyes and short broad snout. The eyes were so large in proportion to the head that their upper edges projectly slightly above the dorsal surface of the skull, and that surface between the eyes was quite depressed and hollow. Before seeing this specimen I had not noticed any 
differences by which male congers could be distinguished from females of the same size, although I had found that all the large specimens (3 feet long and upwards) were females. I took out this specimen, intending to kill it and examine its generative organs, but before killing it I held it alive in a cloth and gently squeezed its abdomen towards the generative aperture. Thick fluid white milt immediately exuded from the aperture, and when I examined a little of this milt under the microscope, I found it swarming with innumerable ripe spermatozoa in most active motion. As the specimen was not in the least injured by the squeezing, I placed it in a tank by itself and kept it alive for further observation. It was $45 \mathrm{~cm}$. (18 inches) long.

Two days afterwards I found a small conger dead in another tank. This also proved to be a ripe male; its length was $51 \mathrm{~cm}$. (20 inches). From the front of the eye to the end of the snout measured $19 \mathrm{~mm}$, the breadth between the eyes $17 \mathrm{~mm}$. The testis was $14 \mathrm{~mm}$. wide $\left(\frac{5}{8}\right.$ inch) and in colour milk-white.

On December 19th eight conger were caught for me near the mouth of Plymouth Sound, with hook and line. They seemed to me to be too large for males, and I concluded they were young females. However I kept them alive; there was one, the smallest, about which I was doubtful, thinking it might be a male. The next day I squeezed this specimen, but could get no milt from it. At this time I was not experienced in detecting the peculiarities of the male in unripe specimens. This specimen when killed and opened proved to be a male with large well-developed almost ripe testes. The specimen was $19 \frac{1}{2}$ inches long $(48 \mathrm{~cm}$.). A piece of the testis examined under the microscope showed no ripe spermatozoa.

I then opened another of the specimens caught on the 19th. I was confident that this one was female, but it proved to be a male with fully-developed but not ripe testes. A few ripe spermatozoa were found on teasing up a portion of the testis. This was the largest male I had yet seen, it was 2 feet 2 inches in length $(66 \mathrm{~cm}$.). The testis on the left side was $3 \mathrm{~cm}$. wide (from attachment to edge). I pressed ripe milt with my finger, after the abdominal cavity was laid open, into the vas deferens at the base of the testis, and thence along the transverse duct behind the rectum to the exterior.

These two males were not darker on the back and sides than a female 2 feet 3 inches long, with which I compared them; in fact both of them were piebald, some parts of the skin being quite light, others dark. But there was a difference in the colour of the ventral surface, which in the female was pure white, entirely without pigment, and in the male was clouded to a considerable degree with black pigment cells. The prominence of the eyes previously described in 
a ripe male was not visible in these last two, which were almost ripe. But I detected another constant difference which enables one to detect a male with almost absolute certainty, whether they be ripe or unripe. In the female the outline of the head when looked at from above is triangular, the snout being pointed; in the male the same outline is much less pointed, the snout being distinctly blunter. Also in the female the dorsal surface of the snout in front of the eyes is arched, so that a transverse section of the dorsal surface is an arc of a circle; in the male the surfaces of the snout are flat, its sides above the mouth being perpendicular, and the upper surface almost level, so that a transverse section forms three sides of a square.

However, I found I still required some practice before I could distinguish males among a number of live conger with certainty. On December 21st I examined three small specimens, and concluded that two were female, while the third was doubtful. I killed the latter, and it proved to be a male $58 \mathrm{~cm}$. (23 inches) long, with very small and undeveloped testes.

Of course the identification of the males is more difficult the smaller and younger the specimens under examination. On January 1st, 1889 , I received four small living conger, which were pale reddish and delicate looking. I decided that two of these were females, and therefore killed them, keeping the other two alive among the males I was collecting. But the two I killed proved to be both males, one of them having the testes very small, while in the other they were moderately developed. One of these specimens was 1 foot 7 inches, the other 1 foot $7 \frac{1}{2}$ inches in length.

Thus, in the course of December, 1888, and January and February, 1889, I collected several small living conger, which I believed to be males, and I kept these in a tank by themselves in order that they might sooner or later develop into a condition of sexual maturity. On March 7th I made an examination of this collection of males. There were eight specimens in all, in addition to the one which was found to be perfectly ripe on December 13th, 1888 . The specimen when handled on March 7th, yielded extremely fluid milt, which under the microscope seemed quite healthy, and was full of active spermatozoa. But the specimen itself was considerably diseased; although it was lively and active when irritated, it had little strength. It was quite blind, one of its eyes being reduced to a loose red ulcerous mass, while the other was clouded and opaque all over the cornea. The skin was also abraded at one or two places on the body. These abrasions appeared as white patches which showed no signs of inflammation. Under the jaw were other abrasions, which were red and inflamed. 
The other eight males were still unripe, none of them yielding milt when squeezed.

The ripe male discovered on December 13th, 1988, died in the aquarium on June 24th, 1889. It had taken no food since it was first found to be ripe on the former date, that is for a period of six months, and before its death had become very thin and feeble, and somewhat crooked as well as blind.

We have now to turn our attention to the history of the large females in the aquarium. Among these there was one which was distinguishable as early as December 17th, 1888, by her large size and by the somewhat distended appearance of the abdominal region. But at this time she was feeding voraciously. In March, 1889, I was told by the attendant that this conger had ceased to feed. Before that I had, with the help of the attendant, caught her in a sac fastened to a large hand-net and squeezed her, but had obtained no trace of eggs. On April 6th I fed the conger myself in order to verify the report that this specimen had ceased to feed, and found it was perfectly true. Never after that date did she take any food.

I carefully watched thisfemale specimen, and occasionally squeezed her carefully after the same method as that already. described. When I tried in June I could obtain no eggs from her; but on July 24th a few eggs were obtained by squeezing. These eggs were very small and were chalk-white in colour. Examined under the microscope, they were perfectly opaque, the vitellus being composed of numerous small spherules; there were no separate oilglobules, and the egg-membrane or envelope was everywhere in close

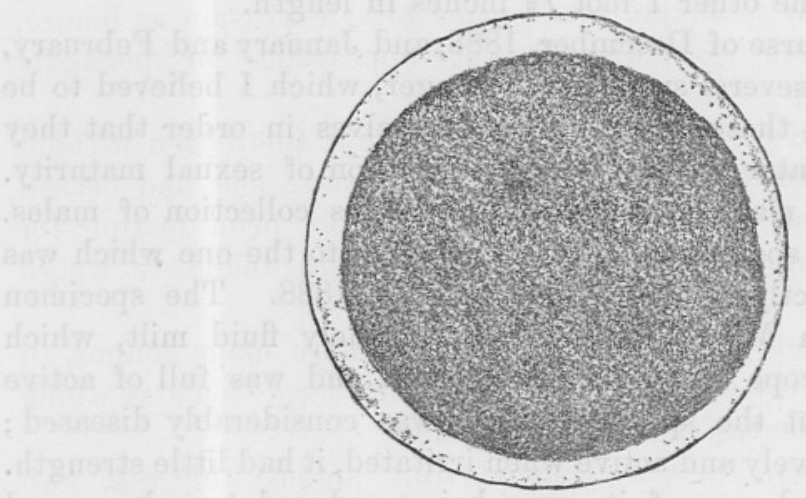

FIG. 3.-Egg of Conger vulgaris squeezed from gravid female July 24th, 1889. Drawn one hour after leaving the parent.

contact with the vitellus. The eggs sank to the bottom in a bottle of sea-water, density 1.027. An hour after extrusion a perivitelline space had developed between the enveloping membrane and the vitellus, as 
shown in Fig. 1, but the latter was as opaque as before, and there was no indication of a germinal disc (blastodisc). The formation of the perivitelline space indicates that these eggs were almost ripe, but it does not follow that they had acquired the characters of the perfectly ripe eggs; it is quite possible, I think, that the eggs might become transparent and buoyant when perfectly ripe. The diameter of one of these eggs after the formation of the perivitelline space was $1.6 \mathrm{~mm}$.

On July 25 th I isolated this female specimen in a separate tank, and placed with her three small specimens identified as males, but the latter were not ripe and did not yield milt on squeezing. I observed no signs of sexual excitement in either female or males when they were thus placed together.

On August 13th I again squeezed the female but got no eggs. After she was released on this occasion it was found that her head was bent down at an angle with the body, and she appeared almost paralysed. Some injury had evidently been done to the vertebral column and spinal cord in the process of handling, but she continued to breathe and lived some time afterwards.

On the 14th and 15th I again tried to squeeze eggs from her, and obtained some separate ova and some small pieces of the ovary. No violence was used in the process, but the ovary is, when enlarged, very soft and tender, and pieces of it are therefore easily detached. The eggs obtained were in the same condition as those obtained in July, I could see no advance in their development; one of them measured $.95 \mathrm{~mm}$. in diameter. A perivitelline space, in most eggs somewhat irregular in shape, was formed after extrusion as before, but the eggs were still without the appearance of perfectly ripe eggs.

This female died on September 10th, having then been without food since April 6th, that is five months at least; she had ceased to feed before that, and had therefore probably been fasting for six months. After her death the ovaries were found to weigh 7 lbs. 5 oz.

In the autumn of 1889 I collected some more male conger, in order to continue my experiments with other large females which were approaching maturity in the aquarium.

On January 24th, 1890, I removed from among the rest two large females which had ceased to feed for some time, and placed them with eight males in a tank from which all other animals had been removed. These males were all ripe or very nearly so, some of them having been ascertained to yield ripe milt when squeezed. Among these specimens unmistakable signs of sexual excitement were observed. The males were generally active and 
restless, but seemed to take a good deal of notice of the females, frequently smelling at their genital apertures. The females rested on the gravel at the bottom of the tank, and constantly swayed from side to side so as to press the abdomen and genital aperture on the gravel. The smaller of the two females rested for days with its head in one of the corners of the tank, and one of the males for some days remained almost constantly by her side, his snout level with hers, his body in the angle between her body and the gravel, on her left side. While he was in this position I frequently noticed a rapid quivering vibration pass along his longitudinal fins, a motion quite different from that of the same fins when used in swimming or in hovering, and only suggestive of sexual excitement. I drove this male away once or twice with a stick, but after one or two digressions he invariably returned slowly to his former position beside the female. Sometimes the female made an excursion up and down the tank, and the male followed her. At other times the male would move away of his own accord, but after a short time would return to his former post beside the female.

While I was absent from the Laboratory in February, through illness, one of the males was taken out dead; it was exceedingly ripe, and was probably the one I saw with the female, for after this I saw no such constant association between a male and female.

On March 23rd I took out this smaller female and very carefully squeezed her abdomen; mucus and blood escaped from the genital aperture together with one free ovum. The ovum was, in all respects, similar to those obtained from the female that died in 1889 . The escape of blood showed that the ovary was ruptured, although the squeezing had been performed very gently; probably, I think, the rupture had taken place before the squeezing. Next day this female was seen to be writhing about and lying on her side. Not long afterwards she was found to be dead. I squeezed her after death and obtained a number of free ova and small pieces of the ovary consisting of eggs fastened together by the scanty ovarian tissue. I placed these eggs in sea-water with some ripe milt from a male, and then kept them in a circulation of sea-water for some days. But though a perivitelline space was formed as before, I never saw any signs of the formation of a blastodisc or of segmentation.

The results of a post-mortem examination were as follows:-The ovaries together weighed $3 \mathrm{lbs} .4 \frac{1}{2} \mathrm{oz}$. The stomach was quite empty, its walls very thin, and containing numerous coiled-up parasitic nematodes or thread-worms. The intestine was very thin, containing only yellow mucus; the stomach and intestines were compressed into the smallest possible space by the enlarged ovaries. All the viscera, including liver and spleen, without the ovaries, weighed $8 \mathrm{oz}$. 
$14 \mathrm{dr}$. Length of the fish 4 feet $5 \frac{1}{2}$ inches; total weight of fish, including everything, $16 \mathrm{lbs} .2 \mathrm{oz}$. $6 \mathrm{dr}$. It may be supposed that by taking out this female and squeezing her I caused her death and prevented the normal extrusion of the ova, but my subsequent experience shows that there is little probability in such a supposition.

It is interesting to compare the above weight and dimensions with those taken from a female which died of disease on February 24th, 1891. This specimen was 4 feet $8 \frac{1}{2}$ inches in length, and weighed 22 lbs. $1 \mathrm{oz}$. The teeth and bones of the head were still normal, and the ovaries immature. In the latter under the microscope the largest eggs were found to be $\cdot 35$ to $.45 \mathrm{~mm}$. in diameter, and to be separated from one another by fat-cells; the eggs were perfectly opaque. The ovaries together weighed $2 \mathrm{lbs}$. The intestine, liver, and other viscera weighed $1 \mathrm{lb} .7 \mathrm{oz}$. The stomach and intestines, although containing no food, were evidently in a normal condition, not collapsed or reduced in size.

From this comparison it follows that the ovaries increase very much in size and weight during the fasting period at the expense of the rest of the body, while in the total weight of the fish a great reduction takes place. It is evident, therefore, that the nutrition of the developing ova consumes not only the fat in the ovary itself, but a large quantity of additional material drawn from the rest of the body.

The second of the two females placed with the males on January 24th died on April 22nd. For two days previously it seemed to be in travail, gasping and twisting itself about as if trying to get rid of its eggs. I expected to find the eggs riper than in the other specimen, but when it was opened I found them rather less developed; none were free, all firmly attached in the ovary; they measured $.97 \mathrm{~mm}$. in diameter $\left(1 \mathrm{~mm} .=\frac{1}{25}\right.$ inch). The length of the fish was 5 feet 11 inches, weight $28 \mathrm{lbs} .9 \mathrm{oz}$; the two ovaries weighed $4 \mathrm{lbs} .5 \mathrm{oz}$. This specimen was never squeezed or handled in any way after its removal from one tank to another on January 24th, so that its death was not due to any mechanical injury.

On March 15th two other female congers which had ceased to feed were removed from the largest tank in the aquarium and placed in the tank where the males were. As it now seemed hopeless to expect any female to produce ripe eggs in the aquarium, I put these two with six ripe males in a box, and sank the box in ten fathoms of water in Plymouth Sound. I occasionally hauled up the box and examined the fish. On August 18th I found one of the females dead, but the other was alive and vigorous. The dead one measured 5 feet 4 inches in length. Its total weight was 33 lbs. 8 oz., of which the ovaries together weighed $7 \mathrm{lbs} .6 \frac{1}{2} \mathrm{oz}$. By counting the 
eggs in a grain of the ovary, I calculated the total number in the two ovaries to be $7,925,280$. Thus the result of my calculation agrees closely with that made at the Southport Aquarium, and therefore the number obtained by Dr. Otto Hermes at Berlin was probably very much too small. The last female I have referred to had taken no food since March 15th, five months.

On August 30th I put the box containing the remaining female down in another part of the Sound, attaching the rope connected with it to the moorings of a buoy. Probably the motion of the buoy broke the rope, for the latter was recovered, but the box could never again be found. The eggs in the female which died in the box were in the same condition as those previously obtained from other females, and the problem of obtaining ripe fertilised eggs still remains unsolved.

When examining the ripe females that died in 1890 (three specimens) I noticed that they had lost nearly all the teeth, and that the bones of the head were soft and flexible. I afterwards made a careful comparison of two of the heads of these specimens preserved in spirit, with the fresh head of a conger bought on the fish-quay on January 6th, 1891. The latter specimen was 4 feet $5 \frac{3}{4}$ inches in length, the total weight $14 \mathrm{lbs}$. $7 \frac{1}{4} \mathrm{oz}$. I found the teeth in this specimen to be as follows:- They are all similar in shape, small, short, and obtusely pointed, and they are very numerous. In each jaw on each side there is one principal row situated on the narrow projecting edge of the jaw. These teeth are very close together, so that their points form a cutting edge. Along the inner side of the gums is a single row of smaller teeth, whose points project but slightly through the gums. At and near the anterior extremity of the premaxilla, on the outer side of the principal row of teeth, are other incomplete longitudinal rows, broadening out into a patch at the extremity of the bone. Similarly in the lower jaw there are incomplete rows on the outer side of the principal row, broadening out into a patch at the anterior extremity of the mandible. In the front of the upper jaw there is an oblong patch of teeth attached to the anterior part of the vomer. All these teeth are very sharp and strong, although small, and are very firmly fixed in the bones which bear them.

In the females which died with ripening ovaries there are only a few scattered teeth left; nearly all of them have disappeared. The few which remain are loose and blunt, held only by the skin, and not firmly fixed in the bones. The prominent ridges of the jawbones on which the principal rows of teeth are situated in the feeding conger have also disappeared, and the surface of the bones within the mouth are smooth and flat. 
The condition of the bones of the head themselves in the conger which have died with ripening ovaries is still more remarkable. The bones are reduced in size, and are so soft and friable that they break easily in the fingers; they offer no resistance when bent, and can be cut with the finger-nail. In order to expose the teeth I cut down from the angles of the mouth with a large knife which was anything but sharp, and the knife cut straight through bones and tissues almost as if it were cutting cheese. In the head of the conger bought on the fish-quay it was impossible to cut through the bones; I had to find the joints, and use a good deal of force to separate the bones from one another.

I also examined the head of a ripe male, and found it was in the same condition, the teeth nearly all gone, the bones in a spongy and soft condition.

The reason of this is probably to be found in the fact that the breeding conger lives so long a time without food. No doubt much of the material of the body is absorbed into the blood and used up in the development of the ova, but probably some of the lime salts to which the bones owe their hardness are excreted.

In any case it is not to be wondered at, since tissues are always undergoing waste, that the bones should degenerate in a fish which takes no food for six months, and in which, further, a large weight of ova is developing at the expense of the rest of the body.

The following two tables give a synopsis of some numerical data related to the observations I have described.

TABLE I.-Numerical data concerning Ripening Female Conger. Specimens examined by me at Plymouth.

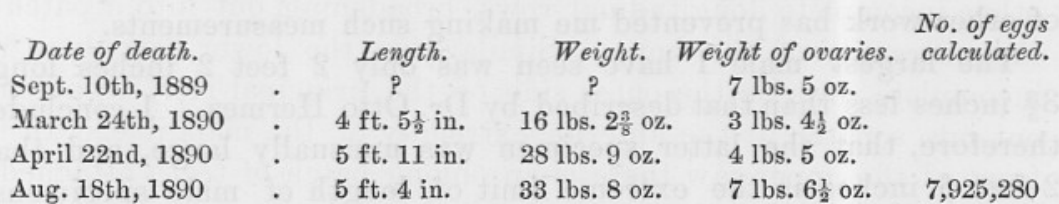

Recorded by Hermes.

$\begin{array}{clllll}\text { ? } & \text { ? } & 22 \text { lbs. } 8 \text { oz. } & 8 \text { lbs. } & 3,300,000 \\ & \text { Recorded by Day. } & & \\ \text { June, } 1876 & ? & 15 \frac{1}{4} \text { lbs. } & 7 \text { lbs. } & 6,336,512\end{array}$


TABLE II.-Showing the Numerical Relation of the Sexes in Conger under 2 feet 6 inches in length, examined by me at Plymouth.

\begin{tabular}{lcccccc}
\multicolumn{1}{c}{ Date. } & No. of specimens. & Males. & & Females. \\
November 17th, 1887 &. & 11 & $\ldots$ & 3 & $\ldots$ & 8 \\
December 20th, 1887 &. & 1 & $\ldots$ & 0 & $\ldots$ & 1 \\
June 6th, 1888 &. & 2 & $\ldots$ & 0 & $\ldots$ & 2 \\
June 14th, 1888 &. & 2 & $\ldots$ & 1 & $\ldots$ & 1 \\
July 4th, 1888 &. & 2 & $\ldots$ & 0 & $\ldots$ & 2 \\
July 21st, 1888 &. & 3 & $\ldots$ & 0 & $\ldots$ & 3 \\
December 7th, 1888 &. & 2 & $\ldots$ & 1 & $\ldots$ & 1 \\
December 20th, 1888 &. & 2 & $\ldots$ & 2 & $\ldots$ & 0 \\
January 2nd, 1889 &. & 6 & $\ldots$ & 2 & $\ldots$ & 4 \\
January 3rd, 1889 &. & 3 & $\ldots$ & 2 & $\ldots$ & 1 \\
& & -34 & & -1 & & 23
\end{tabular}

\section{Discussion of Results of my Observations.}

Some of the conclusions which I have drawn from my observations are certain and others are only probable. Perhaps the most interesting of those which are certain, is that the males are distinguishable from females of the same size by slight but constant secondary sexual characters. The most important of these is the shape of the snout previously described, but I have found the pigmentation of the abdomen to be also a constant difference. The prominence of the eyes I have only noticed in males which were actually ripe. Perhaps careful comparative measurement would have shown that the eye is always larger in the male than in the female, but pressure of other work has prevented me making such measurements.

The largest male I have seen was only 2 feet 2 inches long, $3 \frac{3}{5}$ inches less than that described by Dr. Otto Hermes. I conclude, therefore, that the latter specimen was unusually large, and that 2 feet 6 inches is the extreme limit of length of male specimens. The smallest ripe male I have seen was the first one I obtained, which was only 18 inches in length.

As shown in the table No. 2, according to my experience, even among specimens under 2 feet 6 inches long, the proportion of males is not more than 33 per cent. Brock found males and females about equal in number among 45 specimens. I have only recorded 34 specimens in my note-book, although in collecting living males I examined a larger number. I conclude that the males are less numerous than the females, for it must be remembered that all specimens over 2 feet 6 inches in length are females, and, therefore, 
if the sexes were approximately equal in number we should find the males more numerous than the females among the specimens under 2 feet 6 inches.

Another important conclusion I have drawn from my observations is that each conger only breeds once in its lifetime, or, in other words, that every specimen whether male or female dies after shedding its milt or ova. With regard to the males, I have shown that nothing is easier than to obtain them in the sexually ripe condition by keeping them in an aquarium until they ripen. Of the ripe males which I have had in captivity three have died. I never took out a dead male from the aquarium which was not ripe. Both males and females are very hardy, and during the time I have observed them in our aquarium only one specimen has died, excepting ripe males and females. The other ripe males which $\mathrm{I}$ had in 1890 were lost in the attempt to keep them in a box at the bottom of the sea. It may, of course, be argued that if the females were in natural conditions, and were able to extrude their ripe ova, they would again commence to feed and then breed again. We know that a considerable proportion of other animals die after breeding in consequence of exhaustion, although normally they produce young or eggs a great many times in succession. But, on the other hand, if the conger were able to recover in its normal free state in the sea, it is extremely unlikely that it would die so invariably in captivity, after attaining sexual maturity, especially considering that while its sexual organs are immature it is one of the hardiest, healthiest, and most voracious fishes in the aquarium.

Another objection which may be urged is the great variation in size among adult female conger. One of the gravid specimens which died in our aquarium was only 4 feet $5 \frac{1}{2}$ inches long, and just over $16 \mathrm{lbs}$. in weight, while the largest of those I have recorded was only 5 feet 4 inches long, and $33 \mathrm{lbs} .8 \mathrm{oz}$. in weight. And yet specimens are caught at sea which are much larger than this. Day, in his Fishes of Great Britain and Ireland, mentions one $6 \frac{1}{2}$ feet long, weighing 53 lbs., others weighing 84 lbs., 100 lbs., 104 lbs., and 112 lbs., and one measuring 8 feet 3 inches, and weighing $128 \mathrm{lbs}$. But this by no means invalidates my conclusion, for fishes of the same age vary wonderfully in size, as I know from flounders of the same age which I have myself reared in our aquarium. It is probable enough that the age at which in the female conger feeding and growth ceases, and the maturation of the ova begins, may vary in different individuals. It is also all but certain that females of the same age will reach very different sizes, some obtaining more food than others; even where the same supply of food exists, some probably are less voracious, and have less power of assimilation than others. Butter- 
flies of a given species, although they breed only once, exhibit considerable variation in size.

The strongest evidence, however, in support of my conclusion is, I think, the loss of the teeth and the atrophy of the bones, which occurs during the ripening of the sexual organs. A conger, after it had shed its milt or ova, would in all probability be entirely incapable of feeding itself ; without teeth it would be unable to hold its prey, and without food it could not recover its former condition.

Cases of animals dying after breeding once are, of course, not uncommon in the animal, any more than in the vegetable kingdom. Among insects it is rather the rule than the exception. But confining ourselves to the Vertebrata, to which the conger belongs, there are in that class cases of the phenomenon which are well established. The common eel is known to go down to the sea in order to breed, and the young elvers ascend the rivers in spring in countless multitudes, but no adults have ever been known to return. It is very probable that it will ultimately be found that all the members of the eel family (Murænidæ) produce eggs only at the cost of their own lives. Among the Cyclostomata my own investigations have shown conclusively that the hag-fish, Myxine, does not die after breeding. It breeds again and again, for I have taken, both on hooks and in baited traps, numbers of females with ovaries showing the collapsed follicles, from which the eggs had been recently discharged. In fact, in an old female Myxine, the corpora lutea, i.e. the old empty follicles in different stages of atrophy, belonging to successively discharged crops of eggs, can always be seen in the ovary. On the other hand, the river lamprey, Petromyzon planeri, has been shown to die after breeding once. In this last case there is a true metamorphosis from a sexually immature larva, the Ammocœetes, which feeds and grows, to the sexually mature adult, which feeds little or not at all, breeds, and then dies.

With regard to the season of the year at which the spawning of the conger takes place, my observations tend to show that it is not confined to a very short period, but extends over several months. It is impossible to decide how long a period would have elapsed before each of the ripening females I have mentioned shed its ova, if it had lived to do so. If we suppose that another month was required to bring the ova to perfect maturity, then the ova would have been shed in April, May, September, and October. Similarly the female which was observed at Southport would, perhaps, have spawned in July ; whence it may be provisionally inferred that the female conger spawns in summer and autumn from about April to October. But, on the other hand, I have had ripe males in my possession from December to the end of August. If 
we infer from this that some females also become sexually ripe during the same period, then the spawning season is extended from December till October, eleven months in the year. If this inference is correct it becomes very improbable that the month of November should alone be excluded, and thus there is some ground for the conclusion that conger spawn at any season of the year. I shall have to refer to this question again before the end of this paper. It is at least certain that actually ripe males, or gravid females, have been observed in every month of the year except October and November.

The observed fact that both males and females cease to feed when their sexual organs begin to ripen, satisfactorily explains why it is that ripe specimens have never been obtained directly from the sea, but have only been found among conger kept for some time in captivity. For conger are usually caught by baited hooks, and of course can only be captured in that way when they seek their food. Occasionally they are taken in lobster pots, but they enter these also for the sake of the bait. Conger are frequently taken in the beam trawl, but as the gravid females in aquaria lurk constantly in holes and corners, it may reasonably be supposed that in the sea they remain in their hiding-places among the rocks, and that only those which are hunting for prey can ever be captured by the trawl.

The largest ova I have seen in newly-captured conger were $\cdot 7 \mathrm{~mm}$. in diameter; these occurred in a specimen examined in March. In other large specimens the ova varied from $\cdot 2$ to $.5 \mathrm{~mm}$. in diameter. The larger the ova in such specimens taken directly from the sea the smaller the amount of fat-tissue; when the ova are small the fat forms the greater part of the mass of the ovary, but in more fully-developed ovaries the mass of the ova exceeds that of the fat. In the gravid females which died in the aquarium the ova when first shed were .95 to a little over $1 \mathrm{~mm}$. in diameter, and fat was entirely absent from the ovary. It is evident that the fat is deposited at first in the growing ovary in very great quantity, and is afterwards used up for the nutrition of the developing ova. Much of the fat is reabsorbed in this way before the female ceases to feed; the rest is exhausted during the period of fasting. The difference in size between the largest ova observed in conger from the sea, $.7 \mathrm{~mm}$., and the ova of the gravid females from the aquarium, about $1 \mathrm{~mm}$. before the formation of the perivitelline space, may seem small, considering that the ova of the gravid females have been developing for five or six months after the cessation of feeding. But in the feeding conger the large eggs are comparatively few, the rest are of all sizes, and the majority of them are quite undeveloped. In the gravid females all the eggs are of about the same size, so NEW SERIES.-VOL. II, NO. I. 
that the fasting period is devoted not so much to the increase in size of the few large egg's in the ovary, as to the development of the vast numbers of very young eggs which the immature ovary contains.

It was erroneously stated recently in Nature* that a German naturalist had obtained a conger at Zanzibar containing eggs which were $2.5 \mathrm{~mm}$. in diameter. I found that this statement was founded on a short paper published in the Zoologischer Anzeiger, 1890, p. 314, by a Dr. Voeltzkow, describing a gravid specimen, not of Conger, but of some species of Muræna. This specimen contained eggs which were $2.5 \mathrm{~mm}$. in diameter and transparent. But the writer in Nature had misquoted the paper to which he alluded, and had written Conger instead of Muræna. The specimen of Muræna in question was probably more advanced towards sexual maturity than any conger yet described, because its eggs were transparent, and escaped on slight pressure from the genital aperture. But I have not been able to find any description of a female conger containing eggs larger than those described by me in this paper.

\section{The Eggs of the Conger after Deposition.}

My own work has been confined to the study of the adult conger, my efforts having been directed towards the elucidation of the reproduction as the most satisfactory foundation for a future investigation of the development of the fish from the eggs. But there are a number of facts and probabilities concerning sundry stages of the development of the conger which have resulted from occasional observations made from time to time by other naturalists, and I think it will increase the interest of this paper if $I$ add here a brief review of these.

To take the stages in order, we will begin with what is known of the eggs of the conger after they have been deposited by the female and been fertilised. No such developing eggs have yet been identified with certainty. It seems probable in the first place that the eggs are pelagic, that is buoyant and transparent, and each suspended separately and freely during development in the sea-water. One reason for supposing this is that eggs of the vast majority of truly marine fishes are pelagic. The eggs I have seen in gravid female conger are quite opaque and not buoyant; but these were not perfectly ripe, and it is usually the case that pelagic eggs in the ovary are opaque and heavier than sea-water up to the very last period of their maturation. In fact the eggs in an ovary (e.g. that of the sole) ripen in succession,

* See Nature, vol. xlii, p. 654, 1890. 
and while a few are mature and transparent the rest are still opaque. Therefore it would not be at all surprising if the eggs of the conger were transparent and buoyant when perfectly mature and ready for fertilisation. This probability is made almost a certainty by the observation by Voeltzkow, already cited, on the ripe ova in a specimen of Muræna found at Zanzibar. The eggs in this case were perfectly transparent, and, therefore, probably after fertilisation would be pelagic.

The Italian naturalist Raffaele in his valuable paper on the Pelagic Eggs and Larvæ of Fishes occurring in the Gulf of Naples,* published in 1888, described five different kinds of pelagic eggs, which all resembled one another in certain common characters, and which could not be traced with certainty to the parent fish. Raffaele thinks it possible that these eggs belong to various species of the eel family (Murænidæ). He bases this suggestion on the form of the body, the form of the head, and the large number of muscular segments in the larvæ hatched from the eggs. The eggs all agree in having an extremely large perivitelline space, like that of the pilchard's egg, and in the fact that the yolk is not homogeneous but made up of separate vesicles, also like that of the pilchard. This similarity to the eggs of the pilchard is an important matter. For the family Clupeidæ is the only one among the Physostomi hitherto known to include species with pelagic eggs, and these egg's are distinguished from the eggs of Physoclisti by the two characters above mentioned. Therefore it is in the highest degree probable that Raffaele's eggs belong to some family of the Physostomi, and the Murænidæ is the only family among these in Europe whose eggs are not known.

We may consider it, then, as all but proved that the eggs of the Murænidæ are pelagic, and that to Raffaele belongs the credit of discovering them. In size the eggs described by Raffaele agree very well with those of the conger which I have measured. Unfortunately he only gives the diameter of the actual ovum inside the capsule in one case, in which it was 1.2 to $1.3 \mathrm{~mm}$., scarcely larger than the unripe ova of the conger measured by me before the formation of the perivitelline space. The diameter of the external capsule in Raffaele's eggs was 2 to $3 \mathrm{~mm}$., all the five kinds, except one, having a varying number of oil globules. I am not sure that the egg of the conger when ripe is without oil globules, but so far as I could judge it is so. In this case the egg without oil globules among those described by Raffaele is probably that of Conger vulgaris. The larvæ hatched from these eggs were, as I have said, all very similar. Besides the large number of body segments, they all agreed

* Mitt. Zool. Stat. Neap., Bnd. viii. 
in the development, shortly after hatching, of peculiar long teeth in the jaws. After the fifth day from hatching the larvæ all died.

\section{The Larva of the Conger.}

The larval conger has been identified with certainty at a later stage, a transparent peculiar fish, whose nature remained for a long time doubtful, having been recently proved to be the young of the conger.

The history of our knowledge of this stage of the larva is somewhat curious, and I will therefore give a comprehensive summary of it. About the year 1763 a specimen of an unknown transparent fish of small size was captured in the sea near Holyhead by a gentlemen named William Morris, by whom it was given to Pennant, a celebrated zoologist of the last century. Pennant sent it to Lawrence Theodore Gronow, a Dutch ichthyologist living at Leyden, and the latter published a description and figure of it in the first part, issued in 1763, of a work entitled Zoophylacium. Gronow or Gronovius, for he wrote his scientific works in Latin, gave the fish the name Leptocephalus. Pennant himself gave a description and figure in all respects similar to those of Gronovius in his British Zoology, vol. iii, published in 1769. Pennant calls the fish the Morris after the name of its discoverer, and Leptocephalus after Gronow. His definition is: "Small head, body extremely thin, compressed sideways; no pectoral fins." His description is to the following effect:- "The length was 4 inches, head very small, the body compressed sideways, extremely thin and almost transparent, about $\frac{1}{10}$ th inch thick, and in the deepest part about $\frac{1}{3} \mathrm{rd}$ inch in depth, towards the tail the body grew more slender and ended in a point; towards the head it sloped down, the head lying far beneath the level of the back. Eyes large, teeth in both jaws very small. Lateral line straight, sides marked with oblique strokes that met at the lateral line. Aperture to gills large. It wanted the pectoral, ventral, and caudal fins; dorsal fin extremely low and thin, extending the whole length of the back very near the tail. Anal fin of the same delicacy and extending to the same distance from the anus."

In the later edition of the British Zoology of Pennant, which I have not seen, mention is made of the capture of other specimens of the Leptocephalus, one gentleman, a Mr. Hugh Davies, having seen four specimens, three of which were taken in the amusement of prawning below Beaumaris Green. But I believe no improvement of, or addition to, the description was made in this edition. 
The next account from an actual observer which I have seen is that of Colonel Montagu in the Memoirs of the Wernerian Natural History Society vol. ii, 1818. This naturalist says he possessed two specimens taken by Mr. Anstice, of Bridgewater, in the river Pervet, one in 1810, the other in 1811. Both were caught in a hand-net near the surface of the water. Montagu says that Pennant's description is wrong in stating that pectoral and caudal fins were absent. He says his largest specimen was 6 inches long, $\frac{1}{2}$ inch broad, $\frac{1}{16}$ th inch thick; jaws equal in length, teeth numerous and all inclining forwards. Dorsal fin does not extend the whole length of the back as Pennant stated, but commences one third the length of the body from the snout. Pectorals very minute. Pennant's description also omits mention of the minute black specks on the margin of the back and belly.

In Gmelin's edition of Linnæus's Systema Naturæ, 1788, the fish as described by Gronovius had been introduced under the binomial name Leptocephalus Morrisii, and this name is used by Montagu. In all probability Montagu is right in believing that Pennant's fish and his own were the same, and that Pennant's description and figure were erroneous. Montagu's description and figure have been shown by subsequent observers to be correct, and it is therefore rather from him than from Pennant that we should date our knowledge of the form which he calls Leptocephalus Morrisii.

In Loudon's Magazine of Natural History, vol. v, 1832, p. 313, there is a description from actual observation by $\mathrm{R}$. Couch, the Cornish ichthyologist, of a fish which he calls Ophidium pellucidum, but which he says, in a second communication in the same volume, is undoubtedly the same as the Leptocephalus Morrisii of Fleming's British Animals. Fleming's account is simply taken from that of Montagu. Couch says he had seen four specimens and gives the length (presumably of the largest) as $5 \frac{1}{2}$ inches, depth $\frac{1}{2}$ inch. There are only one or two points in which this description by Couch does not agree with that of Montagu. One is that the former does not mention the lateral compression of the fish, although he refers to its great transparency. Another is the statement that one specimen differed from the others in having two bifid teeth projecting forward from the under jaw; in proportion to the size of the fish they might be termed tusks. If we compare this statement with Raffaele's description of the teeth in the larvæ hatched from his unidentified pelagic eggs, we are at once led to conclude that the teeth observed by Couch were the remains of the more prominent and more numerous teeth of a still earlier stage of the conger larva, and Couch's observation confirms the hypothesis that Raffaele's eggs are those of the Murænidæ.

This hypothesis concerning Leptocephali is still more confidently maintained in Günther's Introduction to the Study of Fishes, published in 1880. The same hypothesis has been put forward in two other cases, namely, in that of the large Phyllosoma forms, known to be derived from the Loricate Crustaceans, such as Palinurus, and in that of large Tornariæ, known to be the larvæ of Balanoglossus. In the case of the Tornaria it was found on investigation that the 
In 1833 another specimen of the Leptocephalus Morrisii was described in Loudon's Magazine (vol. vi, p. 530). The observer in this case was Mr. Henry Vietz Deere, of Slapton, Devon, who states that on April 29th, 1833, one of the local fishermen brought to him a small fish apparently dead, which he had carried in his pocket for three hours wrapped in a piece of brown paper. Nevertheless, the fish seemed to be alive, and was therefore placed in a tumbler of salt and water, where it lived for some hours. Mr. Deere identified his specimen as the Leptocephalus of Pennant, being unacquainted with other descriptions, and, like Montagu, he proceeds to correct Pallas's description. He says the body was $5 \frac{1}{2}$ inches in length, $\frac{1}{8}$ inch thick, $\frac{7}{16}$ inch deep from back to belly. It was compressed laterally in a remarkable manner, and was pellucid, bright, and silvery. The head was small, $\frac{1}{4}$ inch long, but straight with the line of the back. The dorsal fin did not extend the whole length of the back, as Pennant said, but commenced $2 \frac{1}{2}$ inches from the snout, and the pectoral fins were present, though small. Deere thought the fish to be allied to the launce, Ammodytes tobianus.

Yarrell's description in his British Fishes, 1st ed., 1836, is based on three specimens which he received from Couch; he does not add anything essential to previous accounts; he says it is usually found among seaweed.

Couch's description in vol. iv of his Fishes of the British Islands, 1865 , is not very instructive, but he gives a good figure, which was doubtless drawn from one of his own specimens. It is a pity he does not say more about the habits and habitat of the fish. He merely says that its usual residence is in shallow water and rocky ground, but it also inhabits the deeper water.

Off the shores of England only this one kind of Leptocephalus has been found, but in the Mediterranean several species are defined by Kaup (Apodal Fish, Lond., 1856-8, and On Some New Genera and Species of Fishes, Ann. Mag. Nat. Hist., vol. vi, 1860). In the latter paper Kaup identifies the L. Spallanzani of Risso's Hist. Nat. de l'Europe Meridionale with the Leptocephalus Morrisii, and says that specimens vary in the development of the teeth, which are sometimes absent, and that in some the tail is longer than the body, in others vice versâ. He says that the species is common at Messina, where it lives in the open sea, not in the seaweed, and is caught in bottles by boys when bathing.

Prof. J. V. Carus was the first, in a pamphlet entitled Ueber die Leptocephaliden, Leipzig, 186i, to suggest that Leptocephalus and allied forms were the larvæ of other fishes; he concluded that Leptocephalus was the larva of Cepola, a genus of rather small, 
laterally compressed fishes, one of which, Cepola rubescens, is British.

But the identification of Leptocephalus with Cepola was obviously erroneous on anatomical grounds, and was completely rejected by other zoologists. An American ichthyologist, Gill, after examining the subject, came to the conclusion (Proc. Acad. Nat. Sc. Philadelphia, 1864) that the typical Leptocephali were the young of congers, and the one considered here, Leptocephalus Morrisii, the young of Conger vulgaris; he referred Hyoprorus, another genus of the Leptocephalidæ, to another genus of the Murænidæ, namely, Nettastoma, which lives in the Mediterranean.

Gill did not give the anatomical comparisons on which his conclusions were based. In his British Museum Catalogue of Fishes, vol. viii, 1870, Dr. Günther confirms Gill's conclusion so far as concerns the derivation of Leptocephalus Morrisii from the conger, but doubts whether the conger is developed from the Leptocephalus. Dr. Günther mentions as evidence for the connection between the two forms, the similarity in the form of the head and its parts, the coincidence in the number of vertebræ (156) and the geographical distribution. But he says the question arises whether the Leptocephalus is a normal stage in the development of the conger, or whether it is an individual arrested in its development at a very early period, yet continuing to grow to a certain size without a corresponding development of its internal organs, and destined to perish without attaining the characters of the perfect animal.

The reasons Dr. Günther gives for the latter view are three :(1) That he has seen a specimen of a conger $4 \frac{1}{2}$ inches long, i.e. smaller than numerous specimens of Leptocephalus Morrisii. (2) Specimens showing apparently a more developed condition, an approach towards the conger, in the more cylindrical body and more elongated snout, nevertheless have still an undeveloped vertebral column; if Leptocephali are abnormally undeveloped forms, some individuals may be more developed than others in certain points. (3) The variations in the form of the body, dentition, \&c., are so great that it is impossible to separate them into specific forms, and this great variability favours the supposition that they are individuals abnormally arrested in their development.

This hypothesis concerning Leptocephali is still more confidently maintained in Günther's Introduction to the Study of Fishes, published in 1880. The same hypothesis has been put forward in two other cases, namely, in that of the large Phyllosoma forms, known to be derived from the Loricate Crustaceans, such as Palinurus, and in that of large Tornariæ, known to be the larvæ of Balanoglossus. In the case of the Tornaria it was found on investigation that the 
larger specimens were the younger, and that the metamorphosis into Balanoglossus was accompanied by a considerable reduction in size. Such a reduction in size is, in fact, a very common feature in metamorphosis. I have found that the larval symmetrical flounder is considerably longer than the metamorphosed asymmetrical fish. It seems to me that the theory of an abnormal continued growth of larvæ, with arrested development, is at present entirely unsupported by evidence, and in any particular case can only be proved by the actual demonstration of the normal development and of the abnormal, together with proof that they are independent of one another.

However, to return to the case of the conger, I find that the French ichthyologist, Dr. Emile Moreau, in his Poissons de la France, tome iii, p. 568, claims to have satisfied himself by anatomical investigation that the Leptocephalus Morrisii is the young Conger vulgaris. Moreau does not refer to any publication of his anatomical researches, or even mention that he ever published his conclusion in any other place than that I refer to, but he states that M. Dareste appropriated his results in a Note sur le Leptocéphale de Spallanzani in the Comptes Rendus, tome lxxvi, 1873, p. 1304. Moreau asserts that Dareste examined his preparations of Leptocephalus and conger, but made no dissections himself.

If the evidence went no further than this, the conclusion that Leptocephalus Morrisii was the larval conger would rest merely on anatomical and zoological resemblances between the two forms. If it had been discovered that the Leptocephalus was developed from the eggs of the conger, proof would still be wanting that the former was a normal stage in the development of the latter, and Günther's theory of the abnormal growth of the larva would remain uncontradicted by observed facts. But the metamorphosis of a Leptocephalus Morrisii into a normal conger has actually been once observed. This observation was made by the distinguished French zoologist, Yves Delage, and is described briefly in the Comptes Rendus, tome ciii, 1886 , p. 698 . The particulars are as follows :Two specimens of Leptocephalus were captured on February 7th, 1886, by the keeper of the Laboratory of Roscoff, in Normandy. One of them was damaged, and was preserved in alcohol The other was uninjured, and was kept alive in a tank of sea water. Unfortunately Delage, strange to say, omits to give the dimensions of these two specimens. On April 18th the living Leptocephalus was still ribbon-shaped and absolutely transparent, all its blood was colourless, and the air-bladder was not visible. On May 1st the skin began to get a little dark, the air-bladder appeared in the form of a silvery streak, the gills began to show a pink colouration. On May 9 th the fish was examined alive under the 
microscope for a few moments, with such care that its health was not imperilled. It was found that the dorsal fin extended a little in front of the posterior extremity of the pectorals ; in the skin scattered black chromatophores were seen, which gave it its general smoky tint; the blood contained chiefly colourless corpuscles. In the tail were seen colonies of red corpuscles, motionless, and unconnected with the blood-vessels. Little by little after this date the body became more cylindrical, the head grew proportionately larger and more square in shape, and at the commencement of July the transformation was complete, the Leptocephalus, originally ribbonshaped and transparent, with a small head, had become a small conger, opaque and coloured, with a cylindrical body and a head like that of the adult conger. The young conger in July, at the com-

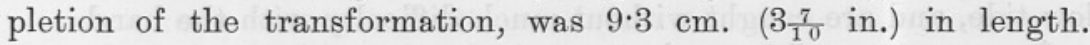
The specimen died from accident on September 5th, and it was then preserved and, together with the other larva preserved in February, presented to the Academy. Delage adds that the Leptocephalus is hatched below the limit of low water, and usually is not found on the shore until after its transformation. He says that it is devoured by the pollack (Gadus pollachius), in the stomach of which it is frequently found.

I will add here one or two remarks concerning Günther's arguments. He states in the Catalogue that he has seen a Leptocephalus 10 inches in length, but does not say it was a Leptocephalus Morrisii. We have seen that the maximum length of English specimens recorded is 6 inches. Of twelve specimens from Messina, whose measurements are given by Kaup, the longest is $5 \frac{1}{3}$ inches (134 mm.), the smallest $4 \frac{1}{5}$ inches. Again, Günther's theory supposes that the abnormal development is due to the fact that the ova and larvæ, which normally develop in the vicinity of the shore, have been carried out to sea far away from land. But we have seen that the Leptocephali captured in England and at Messina have been taken in shallow water near shore, and not in the open sea far from land.

I have found that young conger under 15 inches in length are usually not black or dark like the adults, but pink in colour. I believe this to be due, not to specially coloured pigment cells, but to the small number of black chromatophores which are present in the skin, and which are not sufficient to conceal the natural colour of the tissues of the skin. The smallest of such conger in my collection is $8 \frac{2}{5}$ inches in length $(21 \mathrm{~cm}$.$) , and was taken in the beam trawl off$ St. Agnes Head, on the north coast of Cornwall, April 14th, 1890. Judging from the observation of Delage, this specimen was about a year and a half old, having been a Leptocephalus in the preceding spring, 1889, and hatched in the autumn of 1888 . 
It must be remembered that the young of the common eel, although not so different from the adult as the larva of the conger, is nevertheless perfectly transparent up to a length of about 3 inches, a length fairly corresponding to 6 inches in the case of the conger. These young eels or elvers are common enough in Plymouth Sound in spring from February to May or June, or even later. Unlike the Leptocephalus, they resemble the adult eel in shape, the body being cylindrical, the head like that of the adult, having the lower jaw prolonged, and the pectoral fins well developed. They also have red blood, visible as a small red spot at the throat, which is really the heart, the eyes are perfectly black, and there is a line of black pigment along the spinal cord; otherwise they are transparent as glass. They are often found in tide pools and under stones at low tide, and are caught without much difficulty with the hand.

I regret to say I have not met with any specimens of the Leptocephalus at Plymouth, and if any reader of this Journal can present me with some, alive or preserved, I shall be very thankful. 